\title{
Pengembangan Modul Pembelajaran Kimia Berbasis Augmented Reality
}

\author{
Reski Ramadani \\ Pendidikan Kimia, Universitas Negeri Makassar \\ Email: reskiramadanii@gmail.com \\ Ramlawati Ramlawati \\ Pendidikan Kimia, Universitas Negeri Makassar \\ Email: ramlawaty65@yahoo.com \\ Muhammad Arsyad \\ Pendidikan Fisika, Universitas Negeri Makassar \\ Email: m_arsyad288@yahoo.co.id
}

(Diterima: 17-Desember-2019; direvisi: 18-Januari-2020; dipublikasikan: 17-Maret-2020)

\begin{abstract}
Abstrak: Penelitian ini merupakan penelitian pengembangan bertujuan untuk mengembangkan modul pembelajaran kimia berbasis augmented reality bersifat valid, praktis, dan efektif. modul pembelajaran kimia berbasis augmented reality ini mengacu pada model pengembangan 4-D oleh Thiagarajan, dkk yang meliputi tahap pendefinisian (define), perancangan (design), pengembangan (develop), dan penyebarluasan (disseminate). Modul pembelajaran ini telah melalui tahap validasi oleh validator/ahli dan telah melalui uji coba lapangan, serta mengalami revisi oleh pengembang sehingga menghasilkan modul pembelajaran yang bersifat valid, efektif, dan praktis. Hasil penelitian ini adalah: (1) penilaian kelayakan/kevalidan media oleh 1 ahli media dan 1ahli materi berada pada kategori sangat valid; (2) pada tahap uji coba lapangan kepada 33 peserta didik kelas XI MIA 1 SMAN 10 Makassar memperoleh rata-rata skor tes hasil belajar 80,00 dari skor ideal 100 dengan ketuntasan kelas 82\%; (3) respon peserta didik dan guru untuk modul pembelajaran yang dikembangkan juga memperoleh kategori masing-masing tinggi dan sangat tinggi dengan persentase $80,38 \%$ dan $100 \%$ sehingga modul dikatakan praktis. Maka kesimpulannya adalah modul pembelajaran kimia berbasis augmented reality yang telah dikembangkan dengan model 4D bersifat valid, praktis dan efektif untuk digunakan dalam pembelajaran.
\end{abstract}

Kata kunci: Pengembangan Modul Pembelajaran; Augmented Reality; Senyawa Hidrokarbon.

Abstract: The study is research and development that aims to develop augmented realitybased chemistry learning module which is valid, practical, and effective. Augmented realitybased chemistry learning module refers to the 4-D development model by Thiagarajan et. al., which includes the stages of defining, designing, developing and disseminating. This learning modules had been conducted the validation stage by the assessors or experts and gone through field trial, revised by the developer to produce learning module which is valid, effective, and practical. The results of the study reveal that: (1) the assessments of feasibility or validity of the media expert and a material expert are in the very valid category; (2) in the field trial stage to 33 students of grade XI MIA 1 at SMAN 10 Makassar obtained the mean score of 80.00 learning outcomes from an ideal score of 100 with a grade completeness of $82 \%$; (3) the responses of students and teachers respectively with a percentage of $80.38 \%$ and $100 \%$, so the module is stated as practical. Therefore, the conclusion of the study is the augmented 
reality-based chemistry learning module which had been developed using 4D model is valid, practical, and effective to be applied in learning.

Keywords: Development of Learning Modules; Augmented Reality; Hydrocarbon

Compounds.

\section{PENDAHULUAN}

Kurikulum 2013 menuntut guru untuk melaksanakan proses pembelajaran sebagai proses membangun pengetahuan, keterampilan dan sikap peserta didik, sehingga dalam kegiatan pembelajaran, guru diharapkan menggunakan model, pendekatan dan metode yang tepat untuk menarik minat dan membangun kemampuan peserta didik pada setiap mata pelajaran, khususnya mata pelajaran sains yaitu kimia.

Talanquer (2011) menjelaskan bahwa kimia melibatkan pemahaman dan penerapan konsep. Konsep tersebut dapat direpresentasikan ke dalam berbagai tingkat representasi ganda yang disebut triplet kimia, terdiri atas representasi makroskopik (eksperimen dan pengalaman), simbolik (persamaan kimia, rumus kimia, dan sebagainya) serta sub-mikroskopik (molekul, elektron, atom). Berdasarkan hal tersebut, guru harus memiliki kreatifitas yang tinggi agar dapat membelajarkan kimia di kelas sehingga memudahkan peserta didik memahami setiap konsep.

Penggambaran fenomena yang ada dalam ilmu kimia bisa dilakukan dengan berbagai cara, misalnya dengan melakukan praktikum, menggunakan alat peraga, bahan ajar, ataupun media pembelajaran. Hal ini berkaitan dengan penelitian Slameto (2010) bahwa salah satu faktor yang berpengaruh dalam pencapaian hasil belajar adalah media pembelajaran yang digunakan ketika proses pembelajaran. Sedangkan untuk penggunaan bahan ajar, seperti modul menurut Kusumam, Mukhidin, \& Hasan (2016) memiliki manfaat bagi guru maupun peserta didik yaitu bagi guru bahan ajar yang digunakan sesuai kurikulum, tidak tergantung dengan buku teks dan buku paket bantuan pemerintah, sedangkan untuk peserta didik mampu menciptakan pembelajaran yang menarik, menumbuhkan motivasi, mengurangi ketergantungan dan mendapatkan kemudahan dalam mempelajari setiap indikator yang terdapat pada perangkat pembelajaran yang disusun oleh guru. Melihat hal tersebut maka sangat diperlukan media pembelajaran kimia ataupun bahan ajar yang inovatif dalam proses pembelajaran di kelas.

Keberadaan sebuah media pembelajaran cetak yang mampu membantu belajar peserta didik sangat dibutuhkan, mengingat mata pelajaran kimia merupakan salah satu mata pelajaran yang tergolong sukar. Melihat hal tersebut dibutuhkan bahan ajar berupa modul yang menarik dan interaktif bagi peserta didik. Hal ini sesuai dengan penjelasan Celikler (2010) bahwa modul merupakan salah satu jenis alat bantu berupa perangkat belajar yang digunakan dalam membantu peserta didik untuk belajar mandiri dengan sifat self instructional. Penggunaan modul yang dikembangkan dapat membuat peserta didik berperan aktif dan membantu mereka dalam memahami konsep pembelajaran kimia.

Hasil analisis lebih lanjut, salah satu materi kimia yang membutuhkan pemahaman konsep adalah senyawa hidrokarbon. Dalam materi ini peserta didik harus bisa menggolongkan senyawa hidrokarbon berdasarkan kejenuhan ikatan, memberi nama, menjelaskan sifat fisika dan kimia, dan menentukan isomer senyawa hidrokarbon yang tidak bisa dilakukan hanya dengan menghafal saja, namun membutuhkan pemahaman konsep yang kuat serta penggunaan media pembelajaran inovatif dan interaktif. Sehingga, peserta didik tidak kesulitan dalam memahami konsep yang disajikan.

Solusi yang dapat ditawarkan dari permasalahan tersebut adalah dengan mengembangkan modul pembelajaran kimia berbasis augemented reality pada materi 
senyawa hidrokarbon dilengkapi dengan aplikasi berbasis smartphone android dengan memvisualisasikan gambar dua dimensi (2D) menjadi gambar tiga dimensi (3D). Modul yang selama ini digunakan dalam proses pembelajaran masih memiliki tampilan lay out sederhana dan isi yang hanya berupa materi pokok saja. Hal ini tentunya selain menurunkan minat membaca peserta didik, juga belum memberikan pengetahuan tambahan tentang berbagai aplikasi dalam kehidupan sehari-hari yang berhubungan dengan materi tersebut. Modul yang menarik dengan lay out dan isi yang memberikan pengetahuan tambahan, serta dapat divisualisakan dalam bentuk nyata (3D) selain menampilkan materi pembelajaran akan memberikan motivasi tersendiri bagi peserta didik untuk membaca buku atau modul pelajaran kimia.

Pemilihan media visual bergambar dilengkapi aplikasi visualisasi tiga dimensi (3D) dipilih berdasarkan teori klasifikasi pengalaman belajar menurut Edgar (1969) bahwa pengalaman belajar diperoleh, $75 \%$ melalui indra mata, $13 \%$ melalui indra telinga dan 12\% dari indra lain (Suswina, 2011). Cara yang dapat dilakukan untuk mengvisualisasikan gambar dalam bentuk tiga dimensi salah satunya dapat dilakukan dengan menggunakan teknologi augmented reality (AR).

Augmented reality (AR) adalah teknologi yang menggabungkan benda maya tiga dimensi (3D) kedalam sebuah lingkungan nyata tiga dimensi (Kamelia, 2015). Pengembangan modul pembelajaran kimia menggunakan teknologi augmented reality utamanya pada materi senyawa hidrokarbon sangat diperlukan dalam pembelajaran di kelas, karena materi tersebut memiliki kecocokan karakteristik dengan media yang akan dikembangkan. Materi senyawa hidrokarbon memuat materi tentang senyawa yang terdiri atas unsur atom carbon $(\mathrm{C})$ dan hydrogen $(\mathrm{H})$ dimana memiliki rantai carbon (C) dan atom-atom hydrogen $(\mathrm{H})$ yang saling berkaitan, disamping itu memuat penggolongan hidrokarbon seperti alkana, alkuna, dan alkena. Kesemua sub-materi tersebut dapat divisualisasikan dari bentuk dua dimensi yang ada pada modul menjadi tiga dimensi melalui aplikasi augmented reality sehingga, membuat modul lebih menarik untuk dipelajari peserta didik.

Hasil observasi analisis kebutuhan peserta didik yang dilakukan di SMAN 10 Makassar diperoleh data bahwa $97 \%$ peserta didik menyatakan merasa terbantu dalam memahami pembelajaran kimia jika guru menggunakan bahan ajar lain selain buku paket seperti modul. Data ketertarikan dalam penggunaan modul diperoleh $97 \%$ perserta didik tertarik mempelajari kimia dengan menggunakan modul yang dilengkapi aplikasi visualisasi tiga dimensi melalui smartphone. Berdasarkan latar belakang yang telah diuraikan tersebut, maka peneliti tertarik untuk mengembangkan modul pembelajaran kimia berbasis augmented reality yang dapat digunakan dalam pembelajaran di kelas XI SMA pada materi pokok senyawa hidrokarbon.

\section{METODE}

Jenis penelitian pengembangan atau Research and Development (R\&D) yang bertujuan mengembangkan modul pembelajaran kimia berbasis augmented reality dilakukan dengan mengadaptasi model pengembangan 4D Thiagarajan. Model 4D terdiri dari empat tahap yaitu: 1) pendefinisian (define), 2) perancangan (design), 3) pengembangan (development), dan 4) penyebarluasan (desseminate). Akan tetapi pada penelitian ini, peneliti hanya mengadaptasi tiga tahap. Desain penelitian ini adalah pre-experimental design dengan bentuk one shot case study.

Modul pembelajaran kimia berbasis augmented reality yang telah dikembangkan, divalidasi oleh ahli media dan ahli materi dan diujicobakan di SMA Negeri 10 Makassar, provinsi Sulawesi Selatan, tahun pelajaran 2019/2020. Adapun subjek uji coba penelitian ini adalah peserta didik kelas XI MIA 1 yang terdaftar pada tahun pelajaran 2019/2020. Instrumen penelitian yang digunakan adalah instrumen gaya 
belajar peserta didik, lembar validasi ahli materi, lembar validasi ahli media, dan lembar validasi instrumen, seperti, keterlaksanaan pembelajaran, angket respon guru, angket respon peserta didik, dan tes hasil belajar. Teknik analisis data pada pengembangan modul pembelajaran kimia berbasis augmented reality ini dianalisis secara kuantitatif dan diarahkan untuk menjelaskan kevalidan, keefektifan, dan kepraktisan modul pembelajaran yang dikembangkan.

\section{HASIL DAN PEMBAHASAN}

\section{Pengembangan Modul Pembelajaran Kimia Berbasis Augmented Reality Materi Senyawa Hidrokarbon}

Pengembangan modul pembelajaran kimia berbasis augmented reality yang diharapkan menciptakan modul pembelajaran kimia yang valid, efektif serta praktis untuk digunakan dalam proses pembelajaran. Tahap pengembangan dimulai dari tahap pendefinisian dengan melakukan observasi dan wawancara sebagai analisis kebutuhan dalam penelitian.

Hasil observasi dan wawancara yang dilakukan tersebut, peneliti menganalisis dengan lima tahap yaitu analisis awal-akhir, diperoleh kompetensi inti memahami, menerapkan, menganalisis pengetahuan faktual, konseptual berdasarkan rasa ingin tahunya tentang ilmu pengetahuan, teknologi serta menerapkan pengetahuan prosedural pada bidang kajian yang spesifik sesuai dengan bakat dan minatnya untuk memecahkan masalah dengan kompetensi dasar menganalisis struktur dan sifat senyawa hidrokarbon berdasarkan kekhasan atom karbon dan penggolongannya.

Analisis kebutuhan dan gaya belajar peserta didik, diperoleh bahwa peserta didik kelas XI MIA SMAN 10 Makassar secara umum memiliki semangat dalam belajar, namun bahan ajar yang digunakan oleh guru hanya terbatas pada buku paket yang disediakan di sekolah. Permasalahan lain yang diperoleh adalah minat baca peserta didik masih rendah serta penggunaan gadget oleh peserta didik saat proses pembelajaran di kelas. Sedangkan untuk gaya belajar peserta didik, secara umum mereka memiliki gaya belajar visual, audiotorial serta visualaudiotorial sehingga dengan adanya pengembangan modul berbasis augmented reality dapat meningkatkan minat belajar dan pemahaman konsep peserta didik. Analisis tugas, disesuaikan dengan kompetensi dasar yang tercantum dalam kurikulum 2013 yang berlaku di SMAN 10 Makassar mengenai mata pelajaran Kimia materi pokok senyawa hidrokarbon. Analisis konsep, mengidentifikasi materi pokok dengan menyususn sub materi senyawa hidrokarbon. Selanjutnya merumuskan tujuan pembelajaran sesuai dengan kebutuhan dan kurikulum yang diterapkan saat ini.

Tahap perancangan, peneliti merancang terlebih dahulu modul yang terdiri atas bentuk fisik, bagian pendahuluan, bagian isi dan bagian penutup. Setelah itu kemudian merancang aplikasi visualisasi tiga dimensi berbasis augmented reality terdiri atas desain aplikasi, desain button aplikasi, gambar marker, dan gambar tiga dimensi. Setelah desain pada tahap perancangan selesai, maka dilakukan pembuatan media sesuai prosedur yang telah ditetapkan pada perancangan. Pada pembuatan modul dan pencetakan modul dilakukan oleh peneliti sendiri, sementara pada pembuatan aplikasi, peneliti dibantu oleh programmer.

Tahap pengembangan dilakukan untuk mengetahui kevalidan modul, tahap ini dilakukan dengan melakukan penilaian terhadap modul pembelajaran kimia berbasis augmented reality materi senyawa hidrokarbon. Terdapat 2 ahli yang menilai yakni 1 ahli media dari Dosen Fakultas Teknik UNM dan 1 ahli materi dari Dosen Jurusan Kimia FMIPA UNM memberikan penilaian dan saran perbaikan.

Modul pembelajaran yang telah dinyatakan valid/layak untuk digunakan diimplementasikan pada peserta didik kelas XII MIA 1 SMAN 10 Makassar untuk uji coba terbatas. Uji coba ini bertujuan untuk mengetahui respon awal dan kepraktisan 
modul yang telah dikembangkan. Jumlah subjek uji coba ini adalah 22 peserta didik. Hasil yang diperoleh pada tahap ini adalah peserta didik merasa senang dan termotivasi dalam belajar karena mempermudah mereka dalam menemukan konsep dan teori sendiri. Apalagi mereka dapat melihat secara nyata gambar dua dimensi pada modul menjadi tiga dimensi menggunakan aplikasi sehingga mereka tidak harus membayangkan gambar yang tersedia tetapi melihat secara nyata objek yang ada.

Prosedur selanjunya yang dilakukan setelah tahap uji coba terbatas adalah adalah uji coba lapangan. Uji coba ini bertujuan untuk mengetahui keefektifan dan kepraktisan modul yang dikembangkan. Jumlah subjek penelitian adalah 33 peserta didik Kelas XI MIA 1 SMAN 10 Makassar. Pada tahap ini, peserta didik tampak sangat berminat untuk belajar kimia saat pembelajaran berlangsung. Hal ini dapat diketahui dari respon peserta didik yang diperoleh baik ketika belajar menggunakan modul pembelajaran kimia berbasis augmented reality. Sehingga peserta didik dapat meningkatkan hasil belajarnya dalam pelajaran kimia.

Pengimplementasian modul pada pembelajaran di kelas juga dilakukan untuk melihat keefektifan modul sehingga diharapkan dapat digunakan untuk meningkatkan hasil belajar peserta didik Kelas XI MIA SMAN 10 Makassar utamanya pada materi senyawa hidrokarbon. Oleh karena itu, Peneliti mengukur hasil belajar dengan cara mengumpulkan dan merekapitulasi hasil tes belajar peserta didik mengenai materi pokok senyawa hidrokarbon setelah penggunaan modul pembelajaran kimiab berbasis augmented reality.

Hasil penelitian pengembangan menggunakan augmented reality sesuai dengan penelitian yang dilakukan oleh Mustaqim \& Kurniawan (2017) menjelaskan bahwa melalui augmented reality, guru dapat membuat media pembelajaran yang menyenangkan, interaktif, dan mudah diigunakan. Augmented reality juga dapat menggantikan modul pembelajaran yang belum ada disekolah dalam bentuk virtual atau maya. Peserta didik dapat melihat dan menggunakan modul seperti modul aslinya, namun dalam bentuk virtual.

\section{Kualitas Hasil Pengembangan (Produk)}

a. Data Kevalidan Modul Pembelajaran Kimia Berbasis Augmented Reality Materi Senyawa Hidrokarbon

Validasi modul pembelajaran oleh ahli materi mencakup 2 aspek yaitu isi dan penyajian konten materi. Aspek isi terdiri atas beberapa indikator yaitu kesesuaian materi dengan standar kompetensi dan kompetensi dasar, keakuratan materi, kemutakhiran materi, serta mendorong keingintahuan. Sedangkan untuk aspek penyajian terdiri atas lima indikator yaitu teknik penyajian, pendukung penyajian, penyajian pembelajaran, koherensi dan keruntutan alur pikir. Kemudian data yang diperoleh dari validasi materi dapat dilihat pada Tabel 1.

Tabel 1. Data Penilaian Ahli Materi

\begin{tabular}{clcc}
\hline Aspek Materi & \multicolumn{1}{c}{ Indikator Penilaian } & Skor Total & Rerata Skor \\
\hline \multirow{5}{*}{ Isi } & Kesesuaian Materi dengan SK dan KD & 9 & 3,00 \\
& Keakuratan Materi & 9 & 3,00 \\
& Kemuktahiran Materi & 5 & 2,5 \\
& Mendorong Keingintahuan & 8 & 4,00 \\
\hline Rata-rata Skor Keseluruhan & & 3,125 \\
Kategori Pilihan & Teknik Penyajian & 7 & Valid \\
\hline \multirow{3}{*}{ Penyajian } & Pendukung Penyajian & 12 & 3,50 \\
& Penyajian Pembelajaran & 10 & 4,00 \\
& & & 3,33 \\
\hline
\end{tabular}




\begin{tabular}{lccc}
\hline Aspek Materi & \multicolumn{1}{c}{ Indikator Penilaian } & Skor Total & Rerata Skor \\
\hline \multicolumn{1}{c}{$\begin{array}{l}\text { Koherensi dan Keruntutan Alur } \\
\text { Pikir }\end{array}$} & 5 & 2,50 \\
\hline $\begin{array}{l}\text { Rata-rata Skor Keseluruhan } \\
\text { Kategori Pilihan }\end{array}$ & & 3,33 \\
\hline
\end{tabular}

Berdasarkan tabel 1 dapat diketahui hasil modul pembelajaran kimia berbasis augmented reality pada materi senyawa hidrokarbon oleh ahli materi menunjukkan untuk isi diperoleh rerata skor 3,125 dan untuk aspek penyajian diperoleh rerata skor 3,33. Adapun Secara keseluruhan penilaian ahli materi mencakup seluruh aspek memperoleh rerata skor 3,30 . Sehingga apabila dikategorikan berdasarkan kategori kevalidan, maka rerata skor tersebut termasuk pada kategori valid.

Selain penilaian ahli materi, diberikan pula saran dan masukan terkait pengembangan modul. Berdasarkan data yang diperoleh berupa saran dan komentar dari ahli materi yang telah didapatkan sebelumnya maka dilakukan tindak lanjut berupa revisi atau perbaikan pada modul pembelajaran kimia berbasis augmented reality materi senyawa hidrokarbon.
Perbaikan tersebut antara lain, yaitu memperbaiki soal latihan, konsep yang ada pada modul khususnya materi sifat alkena, dan gambar bagan pada materi keisomeran.

Validasi modul oleh ahli media mencakup beberapa aspek yaitu aspek kegrafikan modul, bahasa, dan media (aplikasi). Aspek kegrafikan modul berfungsi untuk mengetahui kesesuaian ukuran modul, desain sampul modul dan desain modul. Aspek bahasa berfungsi untuk mengetahui tingkat kelugasan, kekomunikatifan modul, dialogis dan interaktif, kesesuaian dengan perkembangan peserta didik serta kaidah bahasa. Aspek Media berfungsi untuk melihat kebermanfaatan aplikasi yang dikembangkan, kualitas desain serta kemudahan dalam pengoperasian. Kemudian data yang diperoleh dari validasi dapat dilihat pada Tabel 2.

Tabel 2. Data Penilaian Ahli Media

\begin{tabular}{llc}
\hline \multicolumn{1}{c}{ Aspek Media } & \multicolumn{1}{c}{ Indikator Penilaian } & Rerata Skor \\
\hline \multirow{2}{*}{ Kegrafikan } & 4,00 \\
& Ukuran Modul & 3,75 \\
& Desain Sampul Modul & 3,67 \\
\hline $\begin{array}{l}\text { Rata-rata Skor Keseluruhan } \\
\text { Kategori Pilihan }\end{array}$ & Lesain Modul & 3,80 \\
& Lugas & Valid \\
\hline \multirow{2}{*}{ Bahasa } & Komunikatif & 3,00 \\
& Dialogis dan Interaktif & 4,00 \\
& Kesesuaian dengan Perkembangan Peserta & 4,00 \\
& Didik & 3,50 \\
Rata-rata Skor Keseluruhan & 4,00 \\
\hline Kategori Pilihan & Kesesuaian dengan Kaidah Bahasa & 3,70 \\
Media (Aplikasi) & Desain & Valid \\
\cline { 2 - 2 } & Navigasi/ Pengoperasian & 4,00 \\
Rata-rata Skor Keseluruhan & 3,83 \\
Kategori Pilihan & & 3,5 \\
\hline
\end{tabular}


Berdasarkan tabel 2 dapat diketahui hasil penilaian modul dilengkapi aplikasi visualisasi tiga dimensi berbasis augmented reality materi senyawa hidrokarbon oleh ahli media menunjukan untuk aspek kegrafikan modul diperoleh rerata skor 3,80 , aspek bahasa diperoleh rerata skor 3,70, aspek media diperoleh rerata skor 3,77 . Sehingga apabila skor semua aspek dikategorikan berdasarkan kategori kevalidan, maka rerata skor tersebut termasuk pada kategori valid.

Selanjutnya berdasarkan penilaian kedua pakar validasi konstruk yang diperoleh dari hasil validasi Gregory sebesar 1,00, sehingga apabila dikonversikan berdasarkan tabel kriteria kevalidan modul menurut Arikunto (2010), maka rerata skor tersebut termasuk pada kategori sangat tinggi. Hal ini berarti kevalidan modul termasuk pada kategori sangat tinggi (sangat valid). Selain penilaian, diperoleh pula saran dan komentar dari ahli media yang selanjutnya dilakukan tindak lanjut berupa revisi atau perbaikan pada modul berbasis augmented reality.

\section{b. Data Kepraktisan Modul Pembelajaran Kimia Berbasis Augmented Reality Materi Senyawa Hidrokarbon}

Untuk melihat kepraktisan modul yang dikembangkan dibutuhkan data dari hasil angket respon peserta didik dan guru serta lembar observasi keterlaksaan perangkat. Data hasil angket respon peserta didik dan guru diperoleh menggunakan angket/kuesioner dan lembar observasi keterlaksanaan perangkat diperoleh dari lembar observasi oleh observer. Penilaian digunakan untuk melihat kepraktisan modul dan aplikasi terkait dengan aspek-aspek manfaat media, desain modul, desain media, pengoperasian aplikasi, kesesuaian tujuan pembelajaran, kualitas materi, dan penyajian konten. Dari aspek-aspek yang ada dijabarkan kedalam indikator-indikator pernyataan yang lebih mudah dipahami oleh peserta didik untuk diisi. Rekapitulasi hasil rata-rata dari respon peserta didik kelas XI MIA 1 berdasarkan setiap aspek penilaian dapat dilihat pada Tabel 3.

Tabel 3. Rekapitulasi Hasil Penilaian Respon Peserta Didik XI MIA terhadap Media Per Aspek

\begin{tabular}{clccc}
\hline No & \multicolumn{1}{c}{ Aspek Penilaian } & $\begin{array}{c}\text { Rata-rata } \\
\text { Nilai }\end{array}$ & $\begin{array}{c}\text { Persentase } \\
(\mathbf{\%})\end{array}$ & Kategori \\
\hline 1 & Manfaat Media & 3,20 & 80,00 & Tinggi \\
2 & Desain Modul & 3,21 & 80,30 & Tinggi \\
3 & Desain Media & 3,15 & 79,00 & Tinggi \\
4 & Navigasi/ Pengoperasian & 3,00 & 76,00 & Tinggi \\
5 & Kesesuaian Tujuan Pembelajaran & 3,30 & 82,50 & Sangat Tinggi \\
6 & Kualitas Materi & 3,26 & 81,50 & Sangat Tinggi \\
7 & Penyajian Konten & 3,34 & 83,50 & Sangat Tinggi \\
\hline \multicolumn{3}{c}{ Total } & $\mathbf{3 , 2 1 5}$ & Tinggi \\
\hline \multicolumn{3}{c}{ Kategori Keseluruhan Penilaian Media } \\
\hline
\end{tabular}

Berdasarkan tabel 3 dapat diketahui hasil respon terhadap modul pembelajaran kimia dilengkapi aplikasi visualisasi tiga dimensi berbasis augmented reality materi senyawa hidrokarbon oleh peserta didik kelas XI MIA 1 SMAN 10 Makassar. Pada aspek manfaat media, rata-rata respon yang diberikan oleh peserta didik 80\% dengan kategori tinggi, pada aspek desain modul, rata-rata respon yang diberikan oleh peserta didik yakni 80,30\% dengan kategori tinggi, pada aspek desain media, rata-rata respon yang diberikan oleh peserta didik yakni $79,00 \%$ dengan kategori tinggi.

Pada aspek navigasi/ pengoperasian media, rata-rata respon yang diberikan oleh peserta didik 76,00\% dengan kategori tinggi. Pada aspek kesesuaian tujuan pembelajaran, 
rata-rata respon yang diberikan oleh peserta didik $82,50 \%$ dengan kategori sangat tinggi, pada aspek kualitas materi, rata-rata respon yang diberikan oleh peserta didik 81,50\% dengan kategori sangat tinggi, pada aspek penyajian konten, rata-rata respon yang diberikan oleh peserta didik 83,50\% dengan kategori sangat tinggi. Berdasarkan tabel 3 juga dapat dilihat respon peserta didik kelas XI MIA 1 untuk keseluruhan aspek diperoleh persentase sebesar $80,38 \%$. Berdasarkan tabel kriteria tingkat respon peserta didik menurut Supardi (2015), maka persentase tersebut termasuk pada kategori tinggi. Selain respon peserta didik terhadap modul yang dikembangkan, diperlukan juga respon dari guru mata pelajaran. Respon digunakan untuk melihat kepraktisan modul dilengkapi aplikasi visualisasi tiga dimensi terkait dengan aspek kesesuaian tujuan pembelajaran, kualitas materi, penyajian konten materi, penyajian self evaluation, manfaat modul, desain modul dan pengoperasian media. Aspek-aspek ini juga kemudian dijabarkan dalam bentuk indikator penilaian yang digunakan oleh guru dalam menilai media.

Adapun penilaian guru terhadap media diberikan oleh guru mata pelajaran kimia kelas XI SMA sebanyak 2 orang guru. Hasil penilaian dari guru dapat dilihat pada Tabel 4.

Tabel 4. Rekapitulasi Hasil Penilaian Guru terhadap Media Per Aspek

\begin{tabular}{|c|c|c|c|c|c|c|c|}
\hline \multirow{2}{*}{ No } & \multirow{2}{*}{ Aspek } & \multicolumn{3}{|c|}{ Guru 1} & \multicolumn{3}{|c|}{ Guru 2} \\
\hline & & $\overline{\boldsymbol{X}}$ & $\%$ & Kategori & $\bar{X}$ & $\%$ & Kategori \\
\hline 1 & $\begin{array}{l}\text { Kesesuaian Tujuan } \\
\text { Pembelajaran }\end{array}$ & 4,00 & 100 & $\begin{array}{c}\text { Sangat } \\
\text { Tinggi }\end{array}$ & 4,00 & 100 & $\begin{array}{l}\text { Sangat } \\
\text { Tinggi }\end{array}$ \\
\hline 2 & Kualitas Materi & 4,00 & 100 & $\begin{array}{l}\text { Sangat } \\
\text { Tinggi }\end{array}$ & 3,40 & 85,00 & $\begin{array}{l}\text { Sangat } \\
\text { Tinggi }\end{array}$ \\
\hline 3 & Penyajian Konten & 4,00 & 100 & $\begin{array}{l}\text { Sangat } \\
\text { Tinggi }\end{array}$ & 3,33 & 83,25 & $\begin{array}{l}\text { Sangat } \\
\text { Tinggi }\end{array}$ \\
\hline 4 & $\begin{array}{l}\text { Penyajian Self } \\
\text { Evaluation }\end{array}$ & 4,00 & 100 & $\begin{array}{l}\text { Sangat } \\
\text { Tinggi }\end{array}$ & 4,00 & 100 & $\begin{array}{l}\text { Sangat } \\
\text { Tinggi }\end{array}$ \\
\hline 5 & Manfaat Media & 4,00 & 100 & $\begin{array}{l}\text { Sangat } \\
\text { Tinggi }\end{array}$ & 4,00 & 100 & $\begin{array}{l}\text { Sangat } \\
\text { Tinggi }\end{array}$ \\
\hline 6 & Desain Media & 4,00 & 100 & $\begin{array}{l}\text { Sangat } \\
\text { Tinggi }\end{array}$ & 3,50 & 87,50 & $\begin{array}{l}\text { Sangat } \\
\text { Tinggi }\end{array}$ \\
\hline 7 & Desain Modul & 4,00 & 100 & $\begin{array}{l}\text { Sangat } \\
\text { Tinggi }\end{array}$ & 3,60 & 90,00 & $\begin{array}{l}\text { Sangat } \\
\text { Tinggi }\end{array}$ \\
\hline 8 & $\begin{array}{l}\text { Navigasi/Pengoperasian } \\
\text { Media }\end{array}$ & 4,00 & 100 & $\begin{array}{l}\text { Sangat } \\
\text { Tinggi }\end{array}$ & 3,67 & 91,75 & $\begin{array}{l}\text { Sangat } \\
\text { Tinggi }\end{array}$ \\
\hline & Jumlah & 4,00 & 100 & $\begin{array}{l}\text { Sangat } \\
\text { Tinggi }\end{array}$ & 3,65 & 91,00 & $\begin{array}{l}\text { Sangat } \\
\text { Tinggi }\end{array}$ \\
\hline
\end{tabular}

Berdasarkan tabel 4 dapat dilihat, secara keseluruhan penilaian guru 1 terhadap modul pembelajaran kimia berbasis augmented reality diperoleh persentase ratarata respon yakni sebesar $100 \%$, yang jika dikonversikan berdasarkan tabel kriteria respon guru menurut Supardi (2015), maka termasuk dalam kategori sangat tinggi. Sementara untuk guru 2 diperoleh presentase rata-rata respon sebesar 90,20\%, yang jika dikonversikan juga berdasarkan tabel kriteria respon guru menurut Supardi (2015), maka termasuk dalam kategori sangat tinggi.

Berdasarkan hasil respon guru terhadap modul pembelajaran kimia materi senyawa hidrokarbon dan aplikasi dapat disimpulkan bahwa modul pembelajaran kimia berbasis augmented reality yang dikembangkan praktis untuk digunakan dalam pembelajaran. 
Uji keterlaksaan perangkat dilakukan oleh observer untuk mengetahui sejauh mana pembelajaran dapat terlaksana dengan menggunakan modul pembelajaran kimia dilengkapi aplikasi visualisasi tiga dimensi berbasis augmented reality materi senyawa hidrokarbon. Aspek-aspek yang diperhatikan dalam observasi keterlaksanaan perangkat secara garis besar yaitu tahap pendahuluan, fase stimulation, fase problem statement, fase data collecting, fase verification, dan fase generelalization. Rekapitulasi hasil observasi keterlaksanaan perangkat dapat dilihat pada Tabel 5.

Tabel 5. Rekapitulasi Hasil Observasi Keterlaksanaan Perangkat

\begin{tabular}{clcc}
\hline \multirow{2}{*}{ No } & \multicolumn{1}{c}{ Aspek } & $\begin{array}{c}\text { Rata-rata Persentase } \\
(\mathbf{\%})\end{array}$ & Kategori \\
\hline 1 & Tahap Pendahuluan & 100 & Sangat Tinggi \\
2 & Fase stimulation & 95,83 & Sangat Tinggi \\
3 & Fase problem statement & 100 & Sangat Tinggi \\
4 & Fase data collecting & 100 & Sangat Tinggi \\
5 & Fase verification & 94,44 & Sangat Tinggi \\
6 & Fase generelalization & 100 & Sangat Tinggi \\
7 & Tahap penutup & 88,89 & Sangat Tinggi \\
\hline & Rata-rata total & 97,00 & Sangat Tinggi \\
\hline
\end{tabular}

Berdasarkan tabel 5 dapat dilihat secara keseluruhan penilaian observer terhadap keterlaksanaan pembelajaran menggunakan modul dilengkapi aplikasi visualisasi tiga dimensi diperoleh rata-rata persentase yakni $97 \%$ yang termasuk dalam kategori sangat tinggi. Hasil penilaian observer menunjukkan bahwa modul pembelajaran dilengkapi aplikasi visualisasi tiga dimensi yang dikembangkan praktis untuk digunakan.

Pengukuran respon peserta didik dan guru serta penilaian observer mengenai keterlaksanaan perangkat setelah menggunakan modul pembelajaran kimia dilengkapi aplikasi visualisasi tiga dimensi berbasis augmented reality materi senyawa hidrokarbon, dapat disimpulkan bahwa modul yang dikembangkan dapat menambah dan meningkatkan minat belajar Kimia peserta didik dalam pelajaran Kimia materi senyawa hidrokarbon pada peserta didik kelas XI SMAN 10 Makassar.

Hasil penelitian pengembangan ini sesuai dengan penelitian yang dilakukan oleh Rogness (2011), yang menyatakan bahwa penggunaan visualisasi dapat membantu peserta didik dalam meningkatkan pemahaman konsep. Menurut
Sudjana \& Rivai (2011) penggunaan media pembelajaran dapat membangkitkan proses berfikir peserta didik dari berfikir kongkret menuju ke berfikir abstrak. Sehingga penggunaan media dalam proses pembelajaran dapat menarik perhatian peserta didik dan membantu mereka dalam belajar sehingga akan lebih memahami apa yang dipelajari. Sementara itu, penelitian sejenis tentang penggunaan teknologi augmented reality dalam pembelajaran kimia yang mendukung hasil penelitian ini yakni, penelitian Silitonga (2009), bahwa respon guru terhadap aplikasi HAR (Hydrocarbon Augmented Reality) dalam pembelajaran materi hidrokarbon tergolong tinggi.

$\begin{array}{llr}\text { c. Data Keefektifan } & \text { Modul } \\ \text { Pembelajaran Kimia } & \text { Berbasis } \\ \text { Augmented Reality } & \text { Materi } & \text { Senyawa } \\ \text { Hidrokarbon } & & \\ \text { Keefektifan } & \text { modul } & \text { yang }\end{array}$
dikembangkan dapat dilihat dari data hasil belajar peserta didik. Data hasil belajar peserta didik diperoleh menggunakan tes hasil belajar yang dikerjakan peserta didik setelah melaksanakan pembelajaran. Tes hasil belajar bertujuan untuk mengetahui tingkat pemahaman peserta didik tentang 
materi senyawa hidrokarbon setelah belajar menggunakan modul pembelajaran yang dikembangkan. Hasil analisis tes hasil belajar digunakan untuk mengetahui keefektifan modul dalam kelas, seperti pada Tabel 6 .

Tabel 6. Hasil Analisis Deskriptif Tes Hasil Belajar Peserta Didik

\begin{tabular}{lc}
\hline \multicolumn{1}{c}{ Variabel } & Nilai Deskriptif \\
\cline { 2 - 3 } & X MIA 1 \\
\hline Subjek Penelitian & 33 \\
Nilai Ideal & 100 \\
KKM & 75 \\
Skor Maksimum & 100 \\
Skor Minumum & 60 \\
Jumlah peserta didik yang tuntas & 27 \\
Jumlah peserta didik yang tidak tuntas & 6 \\
\hline \multicolumn{1}{c}{ Persentase Ketuntasan Kelas } & $82 \%$ \\
\hline
\end{tabular}

Berdasarkan data tes hasil belajar menggunakan tes pilihan ganda yang terdiri dari 25 butir soal senyawa hidrokarbon diperoleh dari 33 peserta didik kelas XI MIA 1 SMAN 10 Makassar 27 peserta didik memenuhi kriteria ketuntasan minimal $(\mathrm{KKM})$, sehingga persentase ketuntasan kelas adalah $82 \%$. Berdasarkan persentase ketuntasan tersebut, terlihat bahwa persentase ketuntasan kelas bada kelas XI MIA 1 SMAN 10 Makassar lebih besar dari persen ketuntasan kelas minimum yaitu $80 \%$. Maka dapat disimpulkan modul pembelajaran kimia dilengkapi aplikasi visualisasi tiga dimensi berbasis augmented reality materi senyawa hidrokarbon, efektif untuk digunakan dalam proses pembelajaran.

Hasil penelitian pengembangan ini terhadap keefektifan modul sudah sesuai dengan teori Lukman \& Ishartiwi (2014) yang menyatakan bahwa pengembangan bahan ajar, seperti modul pada proses pembelajaran perlu dilakukan agar terciptanya pembelajaran yang efektif dan efisien. Sedangkan Suryani, Suhery, \& Ibrahim (2014) menjelaskan bahwa dengan menggunakan bahan ajar berbentuk modul, peserta didik lebih mudah mengikuti pembelajaran kimia sehingga proses pembelajaran dapat berlangsung efektif, dan modul yang digunakan dapat membuat peserta didik belajar mandiri dan mempersingkat waktu belajar. Hal ini juga diperkuat oleh Wagiran (2006) yang telah melakukan penelitian dalam pembelajaran menggunakan modul menunjukkan bahwa dengan menggunakan modul dapat meminimalkan miskonsepsi mahasiswa, meningkatkan aktivitas belajar dan hasil belajar mahasiswa.

\section{SIMPULAN DAN SARAN}

Berdasarkan hasil analisis dan pembahasan hasil penelitian yang telah dilakukan, maka dapat disimpulkan bahwa modul pembelajaran kimia dilengkapi aplikasi visualisasi tiga dimensi (3D) berbasis augmented reality materi senyawa hidrokarbon menggunakan model discovery learning dikembangkan dengan menggunakan model pengembangan 4D oleh Thiagrajan yang terdiri atas pendefinisian (define) perancangan (design) pengembangan (development) untuk menghasilkan modul yang valid, praktis dan efektif.

Modul pembelajaran Kimia dilengkapi aplikasi visualisasi tiga dimensi (3D) berbasis augmented reality materi senyawa hidrokarbon dinyatakan valid dengan kategori Sangat tinggi, praktis dengan kategori Sangat tinggi, dan efektif untuk digunakan dalam pembelajaran karena nilai hasil belajar peserta didik telah melewati persen nilai ketuntasan kelas. 


\section{DAFTAR RUJUKAN}

Arikunto, S. 2010. Prosedur Penelitian. Jakarta: PT. Rineka Cipta.

Celikler, D. 2010. The Effect of Worksheet Developed for the Subject of Chemical Compounds on Student Achievement and Permanent Learning. The International Journal of Research in Teacher Education, $1(1), 42-51$.

Edgar, D. 1969. Audio Visual Methods in Teaching. New Yorg: Holt, Rinehart and Winston Inc. The Dryden Press.

Kamelia, L. 2015. Perkembangan Teknologi Augmented Reality Sebagai Media Pembelajran Interaktif pada Mata Kuliah Kimia Dasar. Jurnal ISTEK, 9(1), 238-253.

Kusumam, A., Mukhidin, \& Hasan, B. 2016. Pengembangan Bahan Ajar Mata Pelajaran Dasar dan Pengukuran Listrik untuk Sekolah Menengah Kejuruan. Jurnal Pendidikan Teknologi dan Kejuruan (JPTK), 23(1), 28-39.

Lukman \& Ishartiwi. 2014. Pengembangan Bahan Ajar dengan Model Mind Mapp untuk Pembelajaran Ilmu Pengetahuan Sosial SMP. Jurnal Inovasi Teknologi Pendidikan, 1(2), 109-122.

Mustaqim, I., \& Kurniawan, N. 2017. Pengembangan Media Pembelajaran Berbasis Augmented Reality. Jurnal Edukasi Elektro, 1(1), 36-48.

Rogness, J. (2011). Mathematical Visualitation. Journal of Mathematics Education at Teachers College. 2(2), 1-7.

Silitonga, H. 2009. Perancangan dan Implementasi Interaksi Media Pembelajaran Hidrokarbon Berbasis Teknologi Augmented Reality. Tesis: Institut Teknologi Bandung.

Slameto. 2010. Belajar dan Faktor yang Mempengaruhinya. Jakarta: PT Renika Cipta.

Sudjana, N., \& Rivai, A. 2011. Media Pengajaran. Bandung: Sinar Baru Algensindo.
Supardi. 2015. Penilaian Autentik Pembelajaran Afektif, Kognitif, dan Psikomotorik (Konsep \& Aplikasi). Jakarta: Rajawali Press.

Suryani, D. I., Suhery, T., \& Ibrahim, A. R. 2014. Pengembangan Modul Kimia Reaksi Reduksi Oksidasi Kelas X SMA. Jurnal Pendidikan Kimia, 1(1), 18-28.

Suswina, M. 2011. Hasil Validitas Pengembangan Bahan Ajar Bergambar Disertai Peta Konsep untuk Pembelajaran Biologi SMA Semester 1 Kelas XI. Jurnal Ta'dib, 14(1), 44-51.

Talanquer, V. 2011. Macro, Submicri and Symbolic: The Many Faces of the Chemistry "triplet". International Journal of Science Education, 33(2), 179-195.

Wagiran. 2006. Meningkatkan Keaktifan Mahasiswa dan Reduksi Miskonsepsi Melalui Pembelajaran Konstruktivistik model Kooperatif Berbantuan Modul. Jurnal Ilmu Pendidikan (JIP), 13(1), 25-32. 